\title{
Marxismo e Religião: revolução e religião na América Central
}

\author{
Vinicius Pinheiro de Magalhães ${ }^{1}$ \\ https://orcid.org/0000-0002-2909-3517 \\ ${ }^{1}$ Universidade Federal de Sergipe, Programa de Pós-Graduação em Serviço Social, São Cristóvão, SE, Brasil
}

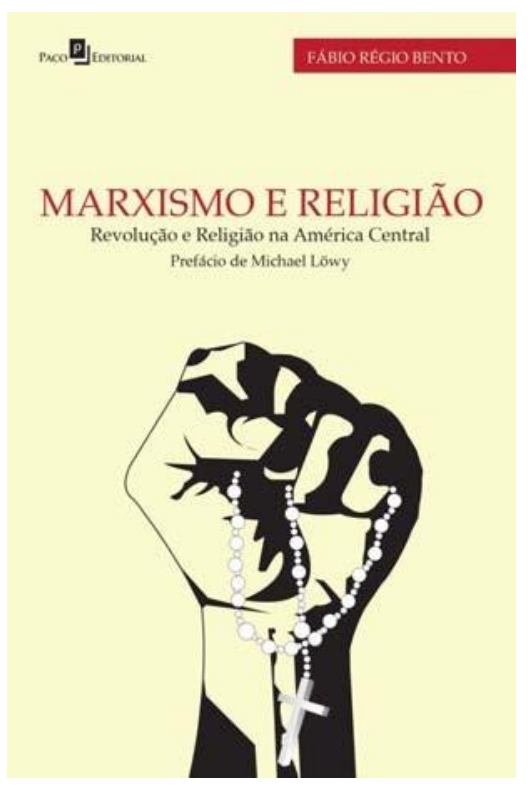

RESENHA: Marxismo e Religião: revolução e religião na América Central

BENTO, Fábio Régio. Marxismo e Religião: revolução e religião na América Central. Jundiaí: Paco, 2016. 100 p.

REVIEW: Marxism and Religion: Revolution and religion in Central America

BENTO, Fábio Régio. Marxismo e Religião: revolução e religião na América Central. [Marxism and Religion: Revolution and religion in Central America]. Jundiaí: Paco, 2016. 100 p.

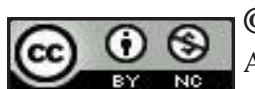

(C) O(s) Autor(es). 2019 Acesso Aberto Esta obra está licenciada sob os termos da Licença Creative Commons Atribuição-NãoComercial 4.0 Internacional (https://creativecommons.org/licenses/by-nc/4.0/deed.pt_BR), que permite copiar, distribuir e reproduzir em qualquer meio, bem como adaptar, transformar e criar a partir deste material, desde que para fins não comerciais e que você forneça o devido crédito aos autores e a fonte, insira um link para a Licença Creative Commons e indique se mudanças foram feitas. 
Fábio Régio Bento fez pós-doutorado em Antropologia Social, é doutor em Ciências Sociais e mestre em Teologia Moral Social. Com esta obra traz uma colaboração evidente para as discussões marxistas brasileiras e latino-americanas. Michel Löwy identifica a Religião (especificamente a católica, tendo em vista as especificidades deste trabalho), retratada nesta obra, como um elemento muito mais complexo do que aquele relacionado ao ópio do povo. Nesse sentido, trata-se de um trabalho que objetiva reinterpretar a lógica da Religião como ópio à luz da história, a fim de responder à questão: “[...] a religião e os agentes religiosos estariam associados mais à conservação política do status quo do que à sua ruptura [?]” (p. 11).

Para responder à questão norteadora de sua pesquisa o autor recorreu a fontes bibliográficas e entrevistas semiestruturadas realizadas com sujeitos (religiosos) que participaram das insurreições populares em El Salvador e na Nicarágua.

Trata-se de um livro curto, o que não significa pouco trabalho, nem simplifica as questões heurísticas desta obra. O texto é dividido em três capítulos: Concepções norteadoras da pesquisa; Religião e revolução na Nicarágua e El Salvador; e Revisão de um equívoco.

No primeiro capítulo, Fábio Bento propõe a exposição de seus pressupostos teóricos que nortearão o desenvolvimento de seu trabalho na medida em que dialoga com a teoria crítica marxiana e marxista, objetivando estabelecer um contraponto à perspectiva da Religião como ópio. Tendo em vista esta empreitada, o autor parte da concepção de Rosa Luxemburgo sobre a Religião. Expõe a denúncia feita pela autora às religiões que desvirtuaram as características primitivas do Cristianismo quanto aos seus ensinamentos sociais; iniciando a obra Marxismo e Religião com uma demonstração argumentativa de um marxismo que entende a possibilidade da Religião como instigadora e revolucionária.

Fábio Bento ainda recorre aos trabalhos de Michel Löwy para interpretar a polêmica afirmação de Karl Marx em Crítica da filosofia do direito de Hegel - Introdução ao considerar a Religião como ópio do povo. O referencial de Löwy permite ao autor desta obra compreender a Religião em sua dimensão complexa e contraditória: de legitimação ou de protesto contra determinada forma de organização da sociedade. Além de permitir também o entendimento da Religião como reflexo das relações materiais de produção - em hermenêutica aos escritos de A Ideologia Alemã - não desconsiderando a potencialidade desse reflexo (ideologia religiosa) no processo de legitimação ou superação de dada forma de sociedade.

O autor, numa perspectiva didático-crítica, lembra ao leitor o fato de as Organizações Religiosas não serem instituições metafísicas, mas organizações absolutamente imanentes ao mundo da concreticidade física, sugerindo que, também nessas instituições, a luta de classes se capilariza. A presença do caráter classista pode ser identificada, por exemplo, no apoio da Religião aos grupos conservadores no âmbito das experiências revolucionárias da China, Cuba e Vietnã. Entretanto, outro fato que revela a presença da luta de classes no âmbito intrarreligioso é o posicionamento da Igreja Católica, em determinado momento histórico, diante da questão social quando da divulgação da encíclica papal Rerum Novarum; com características anticapitalistas e anticomunistas (anticapitalismo romântico). Apesar do caráter reformista dessa experiência, é notória a função social da Religião como algo mais complexo do que simplesmente ópio do povo. Além da perspectiva conservadora e reformista, as experiências de El Salvador e Nicarágua atestam a possibilidade revolucionária oriunda de uma vinculação orgânica com determinada classe social. "As Religiões, em suma, estão dentro das lutas de classes e não fora delas [...]" (p. 22). É nessa perspectiva, a da Religião como potencialmente revolucionária e imersa na luta de classes, que Bento recorre a Otto Maduro para contextualizar e também justificar o lugar da Igreja Católica progressista na luta revolucionária e pela emancipação social dos povos latino-americanos.

Antes de o autor desenvolver seus pressupostos teóricos referentes à Teologia da Libertação latinoamericana, recorre a Bobbio e Brucan para delimitar melhor as características dos grupos religiosos progressistas das Américas. Em Bobbio, o autor dessa obra expõe os conceitos de direita e esquerda associados à compreensão de igualdade pelos grupos ideológicos: para a esquerda a igualdade é horizontalizada e para a direita verticalizada. Em Brucan, o autor sugere a discussão sobre a desigualdade considerando sua dimensão complexa: as desigualdades de classes no espaço nacional e internacional, e as especificidades da identidade nacional. Essas questões podem explicar a influência de Organizações Religiosas no processo de mobilização social para conservação, reformas ou rupturas com modelos de sociedades, tendo em vista a centralidade da identidade nacional (em muitos casos religiosa) como elemento para compreensão da desigualdade e das experiências para sua superação.

Fábio Bento ainda consulta os referenciais da Teologia da Libertação para desenvolver os pressupostos teóricos de seu trabalho. Recorre a Gustavo Gutiérrez para localizar a Teologia da Libertação como um referencial para as lutas de libertação social. Nessa perspectiva as reflexões da referida teologia estão subordinadas ao movimento social, à prática social, e não o contrário. Além de associar essa relação entre Teologia da Libertação e movimento popular à ruptura com determinada forma de sociedade; àquela onde os oprimidos são subjugados. Em consulta ao referencial de Clodovis Boff expõe os três tipos de utopia que caracterizam parte dos elementos 
da Teologia da Libertação: a utopia menor (reformas pontuais); a utopia maior (tratada como a Revolução); e a utopia absoluta (o Reino de Deus). Essa reflexão sugere uma Teologia permanentemente crítica: "A escatologia da libertação obriga sua teologia política a permanecer como instância crítica do que se conquistou no presente". (p. 34). Trata-se, portanto, de uma teologia permanentemente crítica e mudancista, seja numa perspectiva reformista ou revolucionária, dependendo das conjunturas político-sociais de cada nação.

Concluindo o primeiro capítulo, o autor faz uma breve problematização sobre a luta armada, defendida pelos movimentos populares de libertação. Para o autor se estabelece uma moral de duplo efeito quando se adere a uma perspectiva de luta armada. Longe de ser esse o ponto central da Teologia da Libertação, o que se defende é a legítima defesa diante de um Estado ditatorial assassino; o que é expressamente defendido no Catecismo da Igreja Católica. O padre Rogelio, partícipe da luta pela libertação de El Salvador, a este respeito conclui: "La violência es legítima cuando se hace uso de ella em defensa propia y mucho más aún cuando se hace uso de ella em defensa de um pueblo entero" (VIGIL, 1987, p. 53 apud BENTO, 2016, p. 38, grifo nosso).

No segundo capítulo de Marxismo e Religião, Fábio Bento faz uma exposição das características das revoluções de Nicarágua e El Salvador, dando centralidade ao lugar dos segmentos católicos revolucionários.

Na Nicarágua a Revolução se gestou de uma forma limitada, na medida em que promoveu apenas a derrocada da ditadura de Somoza, não constituindo uma transição socialista. Vinte anos após a Revolução Cubana, a Revolução da Nicarágua em 1979, dirigida pela Frente Sandinista de Libertação Nacional (FSLN), inspirada pelo ideal nacionalista de Augusto Sandino e pela Teologia da Libertação, congregou militantes de esquerda religiosos e não religiosos; com especial destaque para sacerdotes católicos que, inclusive, ocuparam cargos importantes no governo revolucionário. Com o processo de derrocada da ditadura de Somoza logo se tornou necessário um governo provisório o que, ainda em 1979, foi criado congregando sandinistas revolucionários e liberais nacionalistas. $\mathrm{O}$ governo misto não extinguiu a luta de classes no interior da Revolução. Setores conservadores apoiados pelo governo norte-americano de Ronald Reagan influenciaram movimentos contrarrevolucionários e militaram no âmbito ideológico objetivando o desgaste da Revolução. A própria Igreja Católica foi refém da luta ideológica norte-americana. Os bispos de Nicarágua e o Papa João Paulo II foram a público manifestar suas discordâncias em relação à Revolução e aos cargos ocupados por padres católicos. A abertura deixada pelos sandinistas para que se gestasse um governo misto de conciliação de interesses foi o que fortaleceu os movimentos contrarrevolucionários e inclusive as divergências futuras entre segmentos da FSLN. Mesmo com sucessivas derrotas eleitorais, a FSLN retoma o poder em 2011 tendo de enfrentar críticas dos próprios companheiros sandinistas revolucionários católicos; o que

[...] as experiências nicaraguense e salvadorenha quebram não com um paradigma marxiano, mas com um equívoco hermenêutico que não teve o ateste da realidade histórica. Portanto, o materialismo de Marx não é um materialismo ateu, tampouco crente. Tratase de um materialismo laico que abre espaço de luta em prol da Revolução para ateus e religiosos. evidencia o caráter permanentemente crítico da Teologia da Libertação, que não se conforma com o instituído e que sempre propõe uma revisão crítica do que se conquistou: uma verdadeira renovação revolucionária.

A história de El Salvador também é marcada pela violência de classe. Trata-se de um país de dominação econômica oligárquica. A elite oligárquica ainda no início do século XX tratou de defender seus interesses mediante repressão com a criação da Guarda Nacional; a ditadura nasce cedo neste país de extrema desigualdade. As sucessões de poder aconteciam de forma fraudulenta, o que influenciou a militância pela libertação nacional de Agustín Farabundo Martí; assassinado pela ditadura na década de 1930. Esse histórico de eleições maquiadas e de extrema desigualdade econômico-social também determinou a criação, na década de 1960, do Partido Democrata Cristão (PDC). O partido e as recentes experiências de mobilização popular da Igreja Católica - a exemplo das Comunidades Eclesiais de Base (CEBs) - começaram a incomodar as elites oligárquicas no decorrer da década de 1970. Entretanto, as reformas pontuais propostas por estes segmentos católicos se mostraram cada vez mais incoerentes com a realidade política de El Salvador, tendo em vista as eleições fraudulentas que impediam qualquer possibilidade de reforma no âmbito do 
Estado. Esse fato deixou clara a necessidade de uma Revolução; ideia que constituiu diversas organizações populares de luta pela emancipação social, a exemplo das Forças Populares de Libertação "Farabundo Martí" (FPL); o Exército Revolucionário do Povo (ERP); a Resistência Nacional (RN); e o Partido Revolucionário dos Trabalhadores Centro-Americanos (PRTC). A união dessas organizações determinou a criação da Frente Farabundo Martí de Libertação Nacional (FMLN), que congregou a guerrilha armada e muitos leigos e religiosos católicos. A década de 1980, em El Salvador, foi um período de guerra declarada em prol da libertação nacional. As forças armadas do Estado, unidas às influências e apoio norte-americanos, promoveram verdadeiras chacinas. O próprio PDC, na representação de José Napoléon Duarte, foi cooptado - e muito bem pago - pelo governo norte-americano para assumir o poder e promover ações apaziguadoras. A partir daí surgem as tentativas de conciliação que na década de 1990 culminam numa institucionalização democrática do país. Em El Salvador, as experiências protagonizadas pela FMLN, que posteriormente se torna um partido político reformista, também não tiveram o caráter de uma Revolução radical, mas influenciaram de forma significativa a construção de uma sociedade democrática.

As duas experiências insurrecionais, de Nicarágua e El Salvador, atestam a possibilidade prática da associação entre a Religião e a Revolução, tendo como matriz ideo-teórica a Teologia da Libertação dirigida por segmentos progressistas de esquerda da Igreja Católica.

No terceiro e último capítulo Fábio Bento propõe a revisão do equívoco da Religião como ópio tendo em vista as experiências insurrecionais vivenciadas por países da América Central. O próprio comandante sandinista Carlos Fonseca percebeu a necessidade de convergência entre a fé e a Revolução, se distanciando da influência ateísta de Moscou. Fidel Castro, líder revolucionário cubano, visitou a Nicarágua em 1980 e se

impressionou com a convergência positiva entre a fé e a Revolução. Frei Betto, em 1985, numa entrevista realizada com Fidel, que posteriormente se torna o livro Fidel e a Religião, destaca que após a visita do líder revolucionário à Nicarágua, sua concepção a respeito da Religião como ópio mudou significativamente. Inclusive, o Estado cubano deixou de ser ateu para se tornar laico numa evidente discordância ao tratamento de Moscou dado a essa questão. O fato é que essas experiências contribuíram para a revisão de um equívoco no seio da esquerda latino-americana, a fim de considerar uma nova hermenêutica de tratamento da relação

Religião-Revolução: a Religião como urtiga revolucionária! Se em tempos de papados conservadores a Teologia da Libertação frutificou e se capilarizou na América Latina, o que esperar do papado de Francisco?

Concluindo seu trabalho, o autor destaca que a Religião como ópio não é um paradigma marxiano, mas uma citação de Marx que não representa seu posicionamento complexo que envolve a questão religiosa. Portanto, as experiências nicaraguense e salvadorenha quebram não com um paradigma marxiano, mas com um equívoco hermenêutico que não teve o ateste da realidade histórica. Portanto, o materialismo de Marx não é um materialismo ateu, tampouco crente. Trata-se de um materialismo laico que abre espaço de luta em prol da Revolução para ateus e religiosos.

Esse trabalho polêmico é de extrema relevância considerando o atual contexto histórico do capitalismo. Cada vez mais grupos religiosos assumem e manifestam uma ideologia reacionária sem medo de exposição, promovendo inúmeras violências aos direitos humanos. $\mathrm{O}$ avanço de comunidades neopentecostais evangélicas e o crescimento da violência contra adeptos de religiões africanas são exemplos claros da capilarização da Religião como ópio e violência. Entretanto, esta obra permite que se vislumbrem possibilidades contrahegemônicas nos espaços religiosos conservadores e reacionários, além de servir de exortação à esquerda brasileira para que não subestime a experiência religiosa como um potencial instrumento de mobilização social. No Brasil, a direita esteve atenta a este caráter instrumental da Religião, sobretudo no contexto das eleições presidenciais de 2018. Nesse sentido, voltar para base - frase que ecoou como dever pós-eleição para a esquerda - também não diz respeito à valorização da espiritualidade das classes populares de nosso País?

\section{Referências}

BENTO, Fábio Régio. Marxismo e Religião: revolução e religião na América Central. Jundiaí: Paco, 2016.100 p.

\section{Vinicius Pinheiro de Magalhães}

viniciuspmaga @gmail.com

Bacharelado em Serviço Social pela Universidade Federal do Recôncavo da Bahia (UFRB)

Mestrando pelo Programa de Pós-Graduação em Serviço Social da Universidade Federal de Sergipe (UFS) 
UFS

Cidade Universitária Prof. José Aloísio de Campos Av. Marechal Rondon, s/n - Jd. Rosa Elze

São Cristóvão - Sergipe - Brasil

CEP: 49.100-000 


\section{Agradecimentos}

O presente trabalho foi realizado com apoio da Coordenação de Aperfeiçoamento de Pessoal de Nível Superior - Brasil (CAPES).

\section{Agência financiadora}

Bolsa de Mestrado da Coordenação de Aperfeiçoamento de Pessoal de Nível Superior (CAPES). Processo: 1771725. Código do financiamento: 001.

Período de execução: março de 2018 a fevereiro de 2020.
Aprovação por Comitê de Ética e consentimento para participação

Não se aplica.

\section{Consentimento para publicação}

Não se aplica.

\section{Conflito de interesses}

Não há conflito de interesses.

\section{Contribuições dos autores}

Não se aplica. 